\title{
Effect of Tillage and Weed Management Practices on Soil Physico-Chemical Characteristics and Wheat Economics
}

\author{
Vivek Kumar Patel ${ }^{1 *}$, R. K. Pathak ${ }^{1}$, Abhay Kumar², Ankit Singh ${ }^{3}$, \\ Samiksha ${ }^{4}$ and Alok Patel ${ }^{5}$
}

${ }^{1}$ Department of Soil Science and Agricultural Chemistry, Acharya Narendra Deva University

of Agriculture \& Technology, Kumarganj, Ayodhya, Uttar Pradesh (224229), India

${ }^{2}$ Department of Agricultural Biotechnology and Molecular Biology, RPCAU, Pusa, Samastipur, Bihar-848125, India

${ }^{3}$ Department of Agronomy, RPCAU, Pusa, Samastipur, Bihar-848125, India

${ }^{4}$ Department of Horticulture, School of Agricultural Science and Technology,

Babasaheb Bhimrao Ambedkar University (A Central University) Vidhyabihar,

RaeBareli Road, Lucknow, Uttar Pradesh, India

${ }^{5}$ Department of Entomology, CSA University of Agriculture and Technology Kanpur,

Uttar Pradesh-208002, India

*Corresponding author

Ke y w o r d s
Conventional
tillage, Clodinafop+
Metsulfuron, Bulk
density, Hand
weeding, Weed
management

Keywords

Conventiona density, Hand weeding, Weed Article Info

Accepted:

12 March 2020 10 April 2020

\section{A B S T R A C T}

Tillage and weed management practices affect physico-chemical characteristics of soils. Therefore, a field study was conducted at Agronomy Research Farm of Narendra Deva University of Agriculture and Technology, Kumarganj, Ayodhya, during rabiseason 201718 with two tillage practices i.e., conventional tillage (CT), Zero tillage (ZT) and three weed management practices i.e., Clodinafop+ Metsulfuron $\left(60+4 \mathrm{~g} \mathrm{ha}^{-1}\right) \mathrm{RM}$, Clodinafop+ Metsulfuron $\left(60+4 \mathrm{~g} \mathrm{ha}^{-1}\right) \mathrm{RM} f b 1$ hand weeding and One hand weeding (45DAS). Effect of these treatments was observed on soil $\mathrm{pH}$, electrical conductivity (EC), bulk density, soil organic carbon content (SOC), and Av. N, P, K and Zn. Among tillage practices, the mean highest SOC was found under $\mathrm{ZT}+\mathrm{R}\left(3.7 \mathrm{~g} \mathrm{~kg}^{-1}\right)$ followed by ZT $\left(3.5 \mathrm{~g} \mathrm{~kg}^{-1}\right)$ and lowest under CT $\left(3.3 \mathrm{~g} \mathrm{~kg}^{-1}\right)$ for soil and weed management was found under Clodinafop + metsulfuron @ 60+4 $\mathrm{g} \mathrm{ha}^{-1}$ (30 DAS) fb 1 hand weeding (45 DAS) $3.6\left(\mathrm{~g} \mathrm{~kg}^{-1}\right)$ followed by Clodinafop+ metsulfuron@ $60+4 \mathrm{~g} \mathrm{ha}^{-1}$ (30 DAS) $3.6\left(\mathrm{~g} \mathrm{~kg}^{-1}\right)$ Mean highest Av. N, P, K and $\mathrm{Zn}\left(\mathrm{kg} \mathrm{ha}^{-1}\right)$ was observed under ZT+R (170.33), (16.64), (282.24) and (7.02) and the lowest under CT 149.67( $\left.\mathrm{kg} \mathrm{ha}^{-1}\right)$, (14.62) $\left(\mathrm{kg} \mathrm{ha}^{-1}\right)$, (248.00) $\left(\mathrm{kg} \mathrm{ha}^{-1}\right)$ and (6.17) ppm for soil and weed management was found under Clodinafop + metsulfuron @ 60+4 $\mathrm{g} \mathrm{ha}^{-1}$ (30 DAS) $f b 1$ hand weeding (45 DAS) $162.60\left(\mathrm{~kg} \mathrm{ha}^{-1}\right), 15.89\left(\mathrm{~kg} \mathrm{ha}^{-1}\right), 269.43\left(\mathrm{~kg} \mathrm{ha}^{-1}\right)$ and $6.70 \mathrm{ppm}$. Effect of tillage and weed management practices on soil $\mathrm{pH}$, EC and bulk density was not significant in the soils. 


\section{Introduction}

Wheat (Triticum aestivum L.) is a staple food of the world and belongs to family Poaceae (Gramineae). It is a C3 plant primarily grown in temperate regions and also at higher altitude under tropical climatic areas in winter season. Wheat is the single most important cereal crop that has been considered as integral component of the food security system of the several nations. It has been described as the 'King of cereals' because of the acreage and high productivity which also occupies a prominent position in the international food grain trade.

Tillage has been part of most agricultural systems throughout history because it achieves many agronomic objectives (e.g., seed bed preparation, soil conditioning, weed suppression and residue management). But, the excessive tillage practices adversely affect soil health, crop productivity and environment quality by affecting soil structure, soil carbon loss and emission of greenhouse gases (Beare et al., 1994).

Wheat (Triticum aestivum L.) is a staple food of the world and belongs to family Poaceae (Gramineae). It is a C3 plant primarily grown in temperate regions and also at higher altitude under tropical climatic areas in winter season. Wheat is the single most important cereal crop that has been considered as integral component of the food security system of the several nations.

It has been described as the 'King of cereals' because of the acreage and high productivity which also occupies a prominent position in the international food grain trade. Wheat provide nearly $55 \%$ of the carbohydrate and $20 \%$ of food calories which is consumed by two billion people $(36 \%$ of the world population) as staple food. Canada, Australia, Pakistan, Turkey, UK, Argentina, Iran and
Italy. These countries contribute about $74.82 \%$ of the total world wheat production. Modified tillage and crop establishment practices are being advocated for improving resource use efficiency and crop productivity in diversified cropping system. Technologies such as zero tillage, conservation tillage and residue management have been fallowed in different crop for conserving resources improving yield and soil health.

Wheat (Triticum aestivum L emend. Fiori \& faol) is the most important crop globally and has received the highest attention for development and promotion of such technologies. In India it is grown on 26 million hectare largely under irrigated conditions following intensive tillage operations.

Zero tillage allow early sowing of wheat reduces the cost of the production. In zero tillage, the crop are shown with minimum disturbance of soil by placing the seed in narrow slit 3-4 cm wide and 4-7 cm deep without land preparation, this optimizes tillage operation, saves water, reduce lodging and ensures better fertilizer use. The weed are major constraints in the adoption of zero tillage technology in Wheat. Although zero tillage reduce the infestation of Phalarisminor, it aggravates the problem of broad leaved weed (Monsef et al., 2016). Effective weed control is important not only to check the yield losses due to weed but also to reduce the nutrient losses.

Optimizing tillage, crop establishment and weed management practices through is essential for improving resource use efficiency and improving soil health. Integrated weed management practices (herbicide + hand weeding) control effective weed in wheat and improve the soil health by entering sun light aeration and enhancing micro flora in soil. 


\section{Materials and Methods}

The study was conducted at Agronomy Research Farm of Narendra Deva University of Agriculture and Technology, Kumarganj, Ayodhya, during rabiseason 2017-18 and the geographical location of Ayodhya district lies between latitude 42.470 and 25.560 North and longitudes 18.120 and 83.980 East and at an altitude of 113 meters in the Gangatic alluvium of Eastern Uttar Pradesh. The experiment involved Tillage and residue management (Main plot) five treatment M1 CT (Transplanted), M2 CT (Transplanted), M3 CT (Direct seeded), M4 ZT (Direct seeded) M5 ZT (Direct seeded) $+\mathrm{R}$ and three Weed management (Sub plot) W1 Clodinafop+ Metsulfuron $\left(60+4 \mathrm{~g} \mathrm{ha}^{-1}\right) \mathrm{RM}$ W2 Clodinafop+ Metsulfuron $\left(60+4 \mathrm{~g} \mathrm{ha}^{-1}\right)$ RM $f b 1$ hand weeding W3 One hand weeding (45DAS) Plots were $11 \mathrm{~m}$ long and 3 $\mathrm{m}$ wide.

The weekly mean minimum and maximum temperatures during the crop season were ranged from 4.7 to $170 \mathrm{C}$ and $13.80 \mathrm{C}$ to $35.200 \mathrm{C}$, total rainfall received was $00.00 \mathrm{~mm}$ during the entire crop season Relative humidity, and sunshine hours were found to varied from 54.4 to 85.6 per cent, and 0.50 to 7.1 hours, respectively. That weekly mean minimum and maximum temperatures during the crop season were ranged from 4.7 to 17 $0 \mathrm{C}$ and $13.80 \mathrm{C}$ to $35.200 \mathrm{C}$, total rainfall received was $00.00 \mathrm{~mm}$ during the entire crop season Relative humidity, and sunshine hours were found to Varied from 54.4 to 85.6 per cent, and 0.50 to 7.1 hours, respectively. Soil $\mathrm{pH}$ was determined (1:2 soil: water suspension) using a $\mathrm{pH}$ meter fitted with a calomel glass electrode (Model Elico LI 127). EC of 1:2 soil: water supernatant (kept overnight) was estimated using a solubridge (model Systronic Conductivity Meter 304). Oxidizable soil organic carbon was estimated using (Walkley and Black 1934) rapid titration method, using a diphenyl amine indicator. Alkaline $\mathrm{KMnO}_{4}$ (potassium permanganate) method as described by Subbiah and Asija (1956) was used to determine available nitrogen in soil samples. Available phosphorus was determined by extracting the soil samples with $0.5 \mathrm{M}$ $\mathrm{NaHCO}_{3}, \mathrm{pH} 8.5$ (Olsen et al., 1954) and measuring the $\mathrm{P}$ content in the extract by colorimetric method using a spectrophotometer at $760 \mathrm{~nm}$ wavelength using ascorbic acid method.

Available potassium content in soil was estimated by extraction of soil with neutral $1 \mathrm{~N} \mathrm{NH4OAc} \mathrm{solution} \mathrm{of} \mathrm{potassium} \mathrm{in} \mathrm{the}$ extract was determined using flame photometer as described by Page et al., (1982). Normal sodium acetate $(\mathrm{NaOAc})(\mathrm{pH}$ 8.2) was used to determine the CEC of the soils following the procedure of Bache (1976).

\section{Results and Discussion}

\section{Available nutrients N, P, K and Zn (kg ha-1)}

The result is indicated that the tillage and weed management practices cause significant effect on available nitrogen, phosphorus, potassium and zinc content. Maximum available $\mathrm{N}\left(170.33 \mathrm{~kg} \mathrm{~h}{ }^{-1}\right), \mathrm{P}(16.64 \mathrm{~kg}$ $\left.\mathrm{ha}^{-1}\right), \mathrm{K}\left(282.4 \mathrm{~kg} \mathrm{ha}^{-1}\right)$ and $\mathrm{Zn}(7.02 \mathrm{ppm})$ were observed Under M5 (ZT+R) treatment where zero tillage + residue were applied in the experimental field.

All the growth, yield attributes and grain and straw yield as affected with the adaptation of various tillage system weed control measures, maximum nutrient contents were recorded under T5 (ZT-ZT) treatments this was mainly due to better soil health (addition of organic matter into soil and Corban sequestration). Maximum uptake of nutrients (N P \& K) was observed under conventional tillage system. 
It was mainly due to Increase in grain and straw yield of wheat under CT-CT treatment, conventional tillage manage the good cultivation technique, environmental condition into soil. The above finding was also related with the Neugsehwandtner et al., (2014) and Kumar et al., (2017) Weed control management did not any significant effect on content the nutrients (N P \& K) while with nutrients uptake were affected significantly, maximum content and uptake of nutrients were observed with W2 treatment where redimix herbicide tone hand weeding applied. This was mainly due to effective herbicide and inter culture operation. They provide better environment condition for absorption of nutrients, herbicide check the weed intensity and inter culture operation enhance the appearance of aeration and sun light into soil. The results are agreement with the Gangwar et al., (2004), Neugsenwandtner (2014), Martineg et al., (2016) (Table 1).
Soil health (Physico-chemical properties of soil after harvesting the wheat)

Data regarding Physico-chemical properties of soil after harvesting the wheat crop have been presented in table 1 . Better improvement in soil health was observed with M5 $(\mathrm{ZT}+\mathrm{R})$ treatment where zero tillage + residue were applied in the experimental field. Maximum organic Corban $\left(3.7 \mathrm{~g} \mathrm{~kg}^{-1}\right.$ ) were observed Under M5 $(\mathrm{ZT}+\mathrm{R})$ treatment. While bulk density (1.50 mg m-3), $\mathrm{pH}$ (8.00) and EC (0.21 dSm-1) was recorded minimum with this treatment (M5) (ZT+R) as compared to the rest of the treatment. Weed management practices did not found significantly on the soil health (Physico-chemical properties of soil) slightly improvement was recorded with the W2 (redimix herbicide + one hand weeding) treatment silt loam texture was recorded in all the treatments.

Table.1 Available nutrients N, P, K and Zn $\left(\mathrm{kg} \mathrm{ha}^{-1}\right)$

\begin{tabular}{|c|c|c|c|c|}
\hline Treatments & $\begin{array}{c}\mathrm{N} \\
\left(\mathrm{kg} \mathrm{ha}^{-1}\right)\end{array}$ & $\begin{array}{c}\mathbf{P} \\
\left(\mathrm{kg} \mathrm{ha}^{-1}\right)\end{array}$ & $\begin{array}{c}\mathrm{K} \\
\left(\mathrm{kg} \mathrm{ha}^{-1}\right)\end{array}$ & Zn (ppm) \\
\hline \multicolumn{5}{|l|}{ Tillage system } \\
\hline $\mathrm{M}_{1}(\mathrm{CT})$ & 149.67 & 14.62 & 248.00 & 6.17 \\
\hline $\mathrm{M}_{2}(\mathrm{ZT})$ & 161.33 & 15.76 & 267.33 & 6.65 \\
\hline $\mathbf{M}_{3}(\mathrm{CT})$ & 155.67 & 15.21 & 257.94 & 6.41 \\
\hline $\mathbf{M}_{4}(\mathbf{Z T}+\mathbf{R})$ & 166.33 & 16.25 & 275.61 & 6.85 \\
\hline $\mathbf{M}_{5}(\mathrm{ZT}+\mathbf{R})$ & 170.33 & 16.64 & 282.24 & 7.02 \\
\hline SEm \pm & 1.88 & 0.19 & 3.12 & 0.08 \\
\hline CD at $5 \%$ & 6.59 & 0.67 & 10.92 & 0.28 \\
\hline \multicolumn{5}{|l|}{ Weed management } \\
\hline $\begin{array}{l}\text { W Clodinafop+metsulfuron } \\
@ 60+4 \mathrm{~g} \mathrm{ha}^{-1} \text { (30DAS) }\end{array}$ & 160.60 & 15.69 & 266.11 & 6.62 \\
\hline $\begin{array}{l}\mathrm{W}_{2} \text {-Clodinafop + metsulfuron } \\
@ 60+4 \mathrm{~g} \mathrm{ha}^{-1} \text { (30 DAS) } f b \\
1 \text { hand weeding (45 DAS) }\end{array}$ & 162.60 & 15.89 & 269.43 & 6.70 \\
\hline $\mathrm{W}_{3^{-}} 1$ hand weeding (45 DAS) & 158.80 & 15.51 & 263.13 & 6.54 \\
\hline SEm \pm & 1.63 & 0.16 & 2.71 & 0.07 \\
\hline CD at $5 \%$ & 4.72 & 0.48 & 7.82 & 0.20 \\
\hline
\end{tabular}


Table.2 Effect of tillage and weed management practices on bulk density and texture classes after harvesting of wheat

\begin{tabular}{|c|c|c|}
\hline Treatments & $\begin{array}{c}\text { Bulk density } \\
\qquad\left(\mathbf{m g ~ m}^{-3}\right)\end{array}$ & $\begin{array}{l}\text { Texture } \\
\text { Classes }\end{array}$ \\
\hline \multicolumn{3}{|l|}{ Tillage system } \\
\hline $\mathrm{M}_{1}(\mathrm{CT})$ & 1.54 & Silt loam \\
\hline $\mathbf{M}_{2}(\mathrm{ZT})$ & 1.51 & Silt loam \\
\hline$M_{3}(C T)$ & 1.54 & Silt loam \\
\hline $\mathrm{M}_{4}(\mathrm{ZT}+\mathrm{R})$ & 1.57 & Silt loam \\
\hline$M_{5}(Z T+R)$ & 1.59 & Silt loam \\
\hline SEm \pm & 0.019 & Silt loam \\
\hline CD at $5 \%$ & NS & Silt loam \\
\hline \multicolumn{3}{|l|}{ Weed management } \\
\hline W1- Clodinafop+ metsulfuron@ $60+4 \mathrm{~g} \mathrm{ha}^{-1}(30 \mathrm{AS})$ & 1.52 & Silt loam \\
\hline $\begin{array}{l}\mathrm{W}_{2} \text {-Clodinafop + metsulfuron @ } 60+4 \mathrm{~g} \mathrm{ha}^{-1} \text { (30 DAS) } \\
\text { fb1 hand weeding ( } 45 \text { DAS) }\end{array}$ & 1.51 & Silt loam \\
\hline $\mathrm{W}_{3^{-}} 1$ hand weeding (45 DAS) & 1.51 & Silt loam \\
\hline SEm \pm & 0.016 & - \\
\hline CD at $5 \%$ & NS & - \\
\hline
\end{tabular}

Table.3 Effect of tillage and weed management practices on $\mathrm{pH}, \mathrm{EC}$ and organic carbon after harvesting of wheat

\begin{tabular}{|c|c|c|c|}
\hline Treatments & pH (1:2.5) & $\mathrm{EC}\left(\mathrm{dSm}^{-1}\right)$ & $\begin{array}{c}\text { O C } \\
\left(\mathrm{g} \mathrm{kg}^{-1}\right)\end{array}$ \\
\hline \multicolumn{4}{|l|}{ Tillage system } \\
\hline$M_{1}(\mathbf{C T})$ & 8.16 & 0.23 & 3.3 \\
\hline $\mathbf{M}_{2}(\mathbf{Z T})$ & 8.13 & 0.23 & 3.5 \\
\hline $\mathbf{M}_{3}(\mathbf{C T})$ & 8.16 & 0.23 & 3.4 \\
\hline$M_{4}(Z T+R)$ & 8.10 & 0.22 & 3.7 \\
\hline$M_{5}(Z T+R)$ & 8.00 & 0.21 & 3.7 \\
\hline SEm \pm & 0.11 & 0.09 & 0.03 \\
\hline CD at $5 \%$ & NS & NS & NS \\
\hline \multicolumn{4}{|l|}{ Weed management } \\
\hline $\mathrm{W}_{1}$ - Clodinafop+ metsulfuron@ $60+4 \mathrm{~g} \mathrm{ha}^{-1}$ (30 DAS) & 8.14 & 0.23 & 3.5 \\
\hline $\begin{array}{l}\mathrm{W}_{2} \text {-Clodinafop + metsulfuron @ } 60+4 \mathrm{~g} \mathrm{ha}^{-1} \text { (30 DAS) } \\
\text { fb } 1 \text { hand weeding (45 DAS) }\end{array}$ & 8.12 & 0.21 & 3.6 \\
\hline $\mathrm{W}_{3^{-}} 1$ hand weeding (45 DAS) & 8.17 & 0.22 & 3.5 \\
\hline SEm \pm & 0.09 & 0.09 & 0.02 \\
\hline CD at $5 \%$ & NS & NS & NS \\
\hline
\end{tabular}


Table.4 Effect of tillage and weed management practices on economics of wheat

\begin{tabular}{|l|c|c|c|c|}
\hline $\begin{array}{l}\text { Treatment } \\
\text { combination }\end{array}$ & $\begin{array}{c}\text { Total cost of } \\
\text { cultivation }\left(\mathbf{F} \mathbf{~ h a}^{-1}\right)\end{array}$ & $\begin{array}{c}\text { Gross income } \\
\left(\mathbf{F} \mathbf{~ h a}^{-1}\right)\end{array}$ & $\begin{array}{c}\text { Net return } \\
\left(\mathbf{F} \mathbf{~ h a}^{-1}\right)\end{array}$ & $\begin{array}{c}\text { B-C } \\
\text { ratio }\end{array}$ \\
\hline T1W1 & 35202 & 101499 & 66297 & $\mathbf{1 . 8 8}$ \\
\hline T1W2 & 38682 & 106058 & 67376 & $\mathbf{1 . 7 4}$ \\
\hline T1W3 & 36722 & 97330 & 60608 & $\mathbf{1 . 6 5}$ \\
\hline T2W1 & 31902 & 75546 & 43644 & $\mathbf{1 . 3 7}$ \\
\hline T2W2 & 35382 & 79190 & 43808 & $\mathbf{1 . 2 4}$ \\
\hline T2W3 & 33422 & 71020 & 37598 & $\mathbf{1 . 1 2}$ \\
\hline T3W1 & 35202 & 96819 & 61617 & $\mathbf{1 . 7 5}$ \\
\hline T3W2 & 38682 & 98859 & 60177 & $\mathbf{1 . 5 6}$ \\
\hline T3W3 & 36722 & 94762 & 58040 & $\mathbf{1 . 5 8}$ \\
\hline T4W1 & 31902 & 82092 & 50190 & $\mathbf{1 . 5 7}$ \\
\hline T4W2 & 35382 & 86608 & 51226 & $\mathbf{1 . 4 5}$ \\
\hline T4W3 & 33422 & 77716 & 44294 & $\mathbf{1 . 3 3}$ \\
\hline T5W1 & 31902 & 87795 & 55893 & $\mathbf{1 . 7 5}$ \\
\hline T5W2 & 35382 & 92204 & 56822 & $\mathbf{1 . 6 1}$ \\
\hline T5W3 & 33422 & $\mathbf{8 4 4 7 0}$ & $\mathbf{5 1 0 4 8}$ & $\mathbf{1 . 5 3}$ \\
\hline
\end{tabular}

Tillage system affected the Physico-Chemical properties of soil basically after harvesting the wheat crop but effect was non-significant on bulk density, soil texture, $\mathrm{pH}, \mathrm{EC}$ and organic Corban while availability was slightly significant on nutrients. Maximum improvement in soil health were observed under M5 (ZT+ZT) followed by M4 (ZT+R), M2 (ZT), M3 (CT) and M1 (CT) treatments respectively. This was mainly due to changing of soil health in soil profile. Tillage intensities being continuous applied for five year, organic Corban-sequestration accumulated system in soil under zero tillage system. Soil fertility slightly influenced /improved in soil profile where the long term zero tillage practices had been maintained. Similar result were also reported by diek (1982), six et al., (1999), Kumar et al., (2016) and 2017, respectively.

Among the weed control management comparative effect of redimix herbicide + one hand weeding treatment was observed as compared to rest of the treatments. Slightly improvement in soil health was recorded under W2 treatment. Clodinofop+ metsulfuron+ one hand weeding check the weed density and promote aeration and pulverization in soil, it involves a bit of rhizosphere soil mixing and this can contributes to enhance microbial activities. The above finding were also agreement with the Dick et al., (1982) six et al., (1999), Kumar et al., 2016 and 2017(Table 2 and 3).

\section{Effect on economics}

The maximum net return of Rs. (67376) was obtained with M1W2 (CT, clodinofop + metsulfuron $60+4 \mathrm{~g} \mathrm{ha}^{-1}$ ) treatment combination while $\mathrm{B}: \mathrm{C}$ ratio was with $\mathrm{M} 1 \mathrm{~W} 1(\mathrm{CT}$, clodinofop + metsulfuron @ 60+4 g ha ${ }^{-1} \mathrm{fb}$ one hand weeding (1.88). Least total cost of cultivation was observed Rs. (31902) with M5W1 (ZT+R clodinafop +metsulfuron $60+4 \mathrm{~g}$ $\left.\mathrm{ha}^{-1}\right)$ treatment. Conventional tillage system was not found economically superior than zero tillage it was due high labour and field preparation cost Conventional tillage system gave better net return per rupee investment, this was mainly due to higher grain and straw yield to greater extent as compared to zero tillage 
system. The results are agreements with- Dick et al., (1982, Gangwar et al., (2004), Verma and Srivastav (1989), Mishra and Singh (2012), Gopinath et al., (2007, Neugsehwandtner et al., (2014) (Table 4).

\section{Acknowledgements}

We would like to thank the Department of Soil Science and Agricultural Chemistry, Acharya Narendra Deva University of Agriculture \& Technology, Kumarganj, Ayodhya, Uttar Pradesh (224229), India for providing all possible research facilities while executing the field experiment and laboratory analysis.

\section{References}

Bache BW (1976). The measurement of cation exchange capacity of soils. J. Sci. Food Agric. 27: 273-80.

Gangwar, K.S, Singh, K.K and shar, S.K, (2004). Effect on tillage on Growth, yield and nutrient uptake in wheat after rice in the IndoGangetic plains of India. Journal of Agriculture Science 4(142): 453-459.

Gopinath, K.A., Kumar, N., Pande, H. And Bisht, J. K. 2007. Bio-Efficacy of herbicides in wheat under zero and conventional Tillage systems. Indian J. Agronomy, 54(1): 58-62.

Kumar R, singh R.S jaidevgajendra S singh R.P (2017) conservation System and weed control measures on yield and soil health in Wheat. Paper presented in BC IS WS udaypurpurrajasthan P. 240

Kumar R, Verma BK, Vedprakesh, Zaid SFA and Dinesh K (2015) Biochemical properties of soil and yield of wheat as influence by Tillage and weed control measures AP and soil Research 17(SP):250 251

Martinejz, Ingrid, Andreas Chervet, Peter Weisskopf, Wolfgang, G Sturny, Ararso Etana, Matthiass Stettler, Johannes forkman and Thomas killer (2016). Two decades of no till in the oberacker long term field experiment part 1 crop yield, soil organic Corban and nutrient distribution in the soil profile. Soil and tillage research, 163: pp 141-151.

Mishra JS and Singh VP (2012). Eeffect of tillage sequence and weed Management on weed dynamic and productivity of rice- wheat Cropping system Indian journal of agronomy 57 (1): 14-19

Neugschwandtner R.W, Liebhard P, Kaul H.P and wagentristl H. (2014). Soil chemical properties as affected by tillage and crop rotation in a long term field experiment. Plant soil environment, 60(2): pp 57-62

Olsen, S.R., Cole, C.V., Watanable, F.S. and Dean, L.A. (1954). Estimation of available phosphorus in soil by extraction with Sodium bicarbonate; USDA, Cric 939:19-23 (C.F., Methods of Soil analysis. Ed. Black, C.A., Agronomy, No.9 AM. Soc. Agron. Inc. Madison, Wisconsin, 1965: 1044-46.

Page A L, Miller L B, Keeney D R (1982). Methods and soil analysis. No. 9, Avon Series ASA-SSSA Publisher, Madison. Wisconsin, USA

Six J, Elliot ET, Paustian K (1999). Aggregate and soil organic matter dynamics under conventional and no-tillage systems. Soil Sci. Soc. Am. J. 63:1350-58.

Subbiah BV, Asija GL (1956). A rapid procedure for the estimation of Available nitrogen in soils. Curr. Sci. 25: 25968

Verma, U.N. and Srivastava, V.C. (1989). Weed management in wheat under zero and optimum tillage condition. Indian J. Agron. 34 (2): 176-179

Walkley, A. and Black, J.A. (1934). An experiment of Degtzariff of Soil organic matter and proposed modification of the chornic Acid titration method. Soil Sci., 37: 29-38.

\section{How to cite this article:}

Vivek Kumar Patel, R. K. Pathak, Abhay Kumar, Ankit Singh, Samiksha and Alok Patel. 2020. Effect of Tillage and Weed Management Practices on Soil Physico-Chemical Characteristics and Wheat Economics. Int.J.Curr.Microbiol.App.Sci. 9(04): 2096-2102. doi: https://doi.org/10.20546/ijcmas.2020.904.252 